\title{
Lifetime Reproductive Performance and Lifespan of SPF C3H Mice Reared under a Single Pair Mating System
}

\author{
Shizuo TOMITA, Tatsuo HAYAO, Haruyasu UCHIDA \\ and Takuya SAWADA
}

Section of Animal and Plant Supply, Division of Technical

Services, National Institute of Radiological Sciences

(Recived for publication: Dec. 17, 1975)

\begin{abstract}
Deta are presented on lifetime reproductive performance (number of fertile matings, litters and mice born and weaned) and lifespan of $\mathrm{C} 3 \mathrm{Hf} / \mathrm{HeMsNrs}$ reared under specific pathogen free conditions. Thirty pairs of mice were mated at the age of $64 \pm 5$ days and maintained under a single pair mating system until either of pair died. No mice died before termination of their reproductive life, therefore, the data of reproductive performance ara based on 30 monogamous pairs. Twenty four pairs out of 30 pairs could produce at least the 6 th litters. In relation to the age of females, $82 \%$ of a total of 210 litters and $87 \%$ of a total of 1,226 offsprings were produced until the age of 250 days. The females gave a maximum litter size, 6.9 at the age between 101 and 150 days. Sex ratio of offsprings did not vary with the age of the females at littes and the parity. It is, however, noteworthy that, when the sex ratio is calculated on mating pair basis it significantly differs from expected ratio of one to one in 5 pairs out of 30 pairs. Among mating pairs, a total number of litters per pair ranged from 3 to 10 litters and a mean total number of offsprings was 41 mice. The ages of females at the last litter born ranged from 128 to 352 days (mean 261 days). The mean lifespan for females and males were 737 and 731 days, respectively. It was not found that there is any correlation between lifespan and lifetime reproductive performance.
\end{abstract}

\section{雌雄同居 (1:1) 飼育による $\mathrm{SPF} \mathrm{C} 3 \mathrm{H}$ マウスの繁殖成績と寿命について}

\author{
富田 静男, 早尾 辰雄 \\ 内田 晴康, 沢田 卓也 \\ 放射線医学総合研究所
}

\begin{abstract}
老化現象の解明は生命科学研究の重要課題の一つであ るが，最近とくにとれに対する関心が高まっている。ま た放射線影響研究の分野においても，老化現象之不可分 の関係を持つと考えられる放射線の生体に対する晚発効 果が重要課題としてとりあげられている。これらの課題 を実験的に追求するにあたっては, 当然実験動物を長期 間にわたって飼育, 観察することが必要であり, したが って, 実験動物を生産, 供給する立場からあ長期飼育, 加令に伴う動物の生理的変化を把握すととが強く望まれ る。生産の場におけるこれらのデータを集積し, 解析す るととは, 動物を使用する側に対し, 実験動物の選択に あたって有益な情報を提供するすのと考えられる。一方,
\end{abstract}

これを繁殖能力の持続性と関連させて捉えれば, 効率的 な動物生産を行なうための交配飼育方法を確立する上に 重要な基礎的資料が得られるものと考えられる。 われわれはこれらの観点から，従来 2,3 の系統のマ ウスについて, 寿命と加令に伴う繁殖生産能力の変化を 検討している。乙の種の長期間にわたる繁殖成績に関し ては，古くは Roberts[6] の体重によって選抜した系 統についての報告があり，最近では西村 $[5]$ が C57BL/ 6Jについて報告しているが，われわれは当研究所におい て SPF のもとに生産飼育されている C3Hf/HeMsNrs マウスの結果について報告する。 


\section{材料と方法}

\section{SPF 動物生産施設の管理}

SPF 動物生産施設で飼育されているマウスはすべて 帝王切開由来で, 無菌 NDII マウスに foster nurseさ れた無菌動物より出発している。本施設への入棟にあた っては，全身シャワーを浴びたのち更衣室に入り，オー トクレーブ滅菌したランニング・シャッ, $\mathrm{T}$ 字帯, くつ した，つなぎ白衣，手術帽，マスク等を着用し，履物は 長靴を使用している。シャワー室および更衣室は, 入室 時を除き，常時殺菌灯を点灯している。更衣室ではさら に逆性石瞼（ハイアミン 200 倍希釈液）を用いて手指消 毒を行なっている。飼料（船橋農場製繁殖用）はオート クレーブにより $120^{\circ} \mathrm{C}, 30$ 分滅菌し, 20分乾燥する。飲 水 (pH8.5) には次亜塩素酸ソーダ（サンラック）を添 加して, 有効塩素10 15ppmに調整し，さらに塩酸を添 加して $\mathrm{pH} 2.5 \sim 3.0$ 亿調整している。給水瓶は次亜塩素 酸ソーダを添加した消毒水槽（有効塩素100〜130ppm） 亿約20時間浸して消毒を行なっている。

飼育室, 廊下等は週 2 回, ハイアミン 200 倍希釈液で 噴霧消毒を行なっている。

微生物の検查方法 100 匹を選び，その新鮮粪を採取し，B H I ブイヨンで 24時間増菌したのち, D H L 平板培地に接種して, 腸内 細菌（サルモネラ，大腸菌）の検査を行なっている。緑 膿菌については, 同様に新鮮糞をNACブイョンに接種 し，48時間後に判定を行なっている。

ネズミコリネ菌，チザー菌については，異なった系統 のマウス各 5 匹にコーチゾンを投与し，7日〜10日後に 剖検して病変の有無により判定を行なっている。

これら 5 種以外の細菌，ウイルスについては約半年に 1 回の割合で, 国立予防衛生研究所に依頼して検査を行 なっている。

本実験開始後 1 年 6 力月（1974年 8 月）で本施設内の
毎月 1 回, 生産施設内のマウスからアト・ランダムに

マウスの一部が緑膿菌に污染されたが，ただちにゲンタ マイシンを経口投与し，乙れにより污染が除去されなか ったマウスを殺処分することによって本施設から緑膿菌 を排除することができた。以後諸検査の結果，本施設の マウス・コロニーは, サルモネラ菌, 大腸菌0115, 緑膿 菌，ネズミコリネ菌，チザー菌，パスッレラ菌，マイコ プラズマ, $\mathrm{HV} \mathrm{J}, \mathrm{MHV}, レ オ 3$, 原虫, 内部寄生虫 に関し，いずれあフリーである。

\section{使用動物}

1972年11月〜12月に生れた C3Hf/HeMsNrs を日令 $65 \pm 4$ 日で雌雄化各30匹を選び， 1 対 1 の同居交配によ り死亡時まで飼育した。仔が産れた場合はその仔を 3 週 令に達するまで同居させた。途中雌雄いずれかが死亡し た場合は，以後生存しているマウスを 1 ケージ，1 1 匹で 飼育した。との 30 ペアのうち最あおそい分婏は 352 日令 であったが，雌雄ともそれ以前の日令で死亡した個体は 1 例むなく，したがって，繁殖成績については30ペア全 部が繁殖生活を完了したものとして集計した。しかし， 寿命については, 死亡日令が不正確なすの数個体を除外 して集計した。日令と繁殖成績との関連については，1 対 1 交配であり，雌雄が全く同一日令ではないので, 雌 雄いずれの繁殖能力の日令の差によるかは判別できない が，ここでは雌親の日令によって解析した。

\section{成}

分婏数と産仔教, 産次および日令との関係

Table 1 亿雙親の日令之産次で分類した分婏の頻度と を30ペアについて集計した結果をしめす。総計 210 回の 分婏があったが，その $80 \%(169 / 210)$ は 6 産次までに 得られている。なお，ての分婏数 210 には死産および分 婏直後の食殺 9 例を含んでいる。

Table 2 に産仔数书よび離乳仔教について同様に分 婏日令と産次とで分類した結果をしめす。総計 1,226 の 仔が得られ，そのうち 1,188 が離乳まで生存した。全産 仔数のうち約 $87 \%$ が 6 産次までに得られている。離乳率

Table 1. Age and parity distributions of the number of litters

\begin{tabular}{|c|c|c|c|c|c|c|c|c|c|c|c|}
\hline $\begin{array}{l}\text { Parity } \\
\text { Age }\end{array}$ & I & II & III & IV & V & VI & VII & VIII & IX & $\mathrm{X}$ & Total \\
\hline-100 & 26 & 2 & & & & & & & & & 28 \\
\hline $101-150$ & 4 & 25 & 22 & 9 & & & & & & & 60 \\
\hline $151-200$ & & 3 & 7 & 15 & 18 & 2 & & & & & 45 \\
\hline $201-250$ & & & 1 & 3 & 5 & 19 & 11 & & & & 39 \\
\hline $251-300$ & & & & 2 & 3 & 3 & 7 & 10 & 4 & 1 & 30 \\
\hline $301-350$ & & & & & & & 1 & 2 & 2 & 2 & 7 \\
\hline $351-400$ & & & & & & & & & 1 & & 1 \\
\hline Total & 30 & 30 & 30 & 29 & 26 & 24 & 19 & 12 & 7 & 3 & 210 \\
\hline
\end{tabular}


Table 2. Age and parity distributions of the number offsprings born and weaned

\begin{tabular}{|c|c|c|c|c|c|c|c|c|c|c|c|c|}
\hline $\begin{array}{l}\text { Parity } \\
\text { Age }\end{array}$ & I & II & III & IV & $\mathrm{V}$ & $\mathrm{VI}$ & VII & VIII & IX & $\mathrm{X}$ & Total & $\begin{array}{l}\text { Weaned } \\
(\%)\end{array}$ \\
\hline-100 & $\begin{array}{c}165 \\
(162)\end{array}$ & $\begin{array}{c}12 \\
(12)\end{array}$ & & & & & & & & & $\begin{array}{c}177 \\
(174)\end{array}$ & 98.3 \\
\hline $101-150$ & $\begin{array}{c}26 \\
(26)\end{array}$ & $\begin{array}{c}161 \\
(159)\end{array}$ & $\begin{array}{c}165 \\
(151)\end{array}$ & $\begin{array}{c}67 \\
(66)\end{array}$ & & & & & & & $\begin{array}{c}419 \\
(402)\end{array}$ & 95.9 \\
\hline $151-200$ & & $\begin{array}{c}24 \\
(24)\end{array}$ & $\begin{array}{c}43 \\
(43)\end{array}$ & $\begin{array}{c}99 \\
(93)\end{array}$ & $\begin{array}{c}111 \\
(110)\end{array}$ & $\begin{array}{c}8 \\
(8)\end{array}$ & & & & & $\begin{array}{c}285 \\
(278)\end{array}$ & 97.5 \\
\hline $201-250$ & & & & $\begin{array}{c}19 \\
(19)\end{array}$ & $\begin{array}{c}31 \\
(31)\end{array}$ & $\begin{array}{c}94 \\
(93)\end{array}$ & $\begin{array}{c}48 \\
(46)\end{array}$ & & & & $\begin{array}{c}192 \\
(189)\end{array}$ & 98.4 \\
\hline $251-300$ & & & & & $\begin{array}{c}16 \\
(16)\end{array}$ & $\begin{array}{c}17 \\
(17)\end{array}$ & $\begin{array}{c}30 \\
(29)\end{array}$ & $\begin{array}{c}45 \\
(42)\end{array}$ & $\begin{array}{c}16 \\
(16)\end{array}$ & $\begin{array}{c}6 \\
(6)\end{array}$ & $\begin{array}{c}130 \\
(126)\end{array}$ & 96.9 \\
\hline $301-350$ & & & & & & & & $\begin{array}{c}6 \\
(6)\end{array}$ & $\begin{array}{c}6 \\
(3)\end{array}$ & $\begin{array}{c}6 \\
(5)\end{array}$ & $\begin{array}{c}18 \\
(14)\end{array}$ & 77.7 \\
\hline $351-400$ & & & & & & & & & $\begin{array}{c}5 \\
(5)\end{array}$ & & $\begin{array}{c}5 \\
(5)\end{array}$ & 100.0 \\
\hline Total & $\begin{array}{c}191 \\
(188)\end{array}$ & $\begin{array}{c}197 \\
(195)\end{array}$ & $\begin{array}{c}208 \\
(194)\end{array}$ & $\begin{array}{c}185 \\
(178)\end{array}$ & $\begin{array}{c}158 \\
(157)\end{array}$ & $\begin{array}{l}119 \\
(118)\end{array}$ & $\begin{array}{c}78 \\
(75)\end{array}$ & $\begin{array}{c}51 \\
(48)\end{array}$ & $\begin{array}{c}27 \\
(24)\end{array}$ & $\begin{array}{c}12 \\
(11)\end{array}$ & $\begin{array}{c}1226 \\
(1188)\end{array}$ & \\
\hline Weaned $(\%)$ & 98.4 & 99.0 & 93.2 & 92.9 & 99.3 & 99.1 & 96.1 & 94.1 & 88.8 & 91.6 & & 96.9 \\
\hline
\end{tabular}

Figures in parenthesis indicate numder of weaned

Table 3. Intervals between litters and age of females at litters

\begin{tabular}{rrrr}
\hline Parity & No. of Mice & $\begin{array}{c}\text { Age at Litter(day) } \\
\text { mean } \pm \text { S. E. }\end{array}$ & $\begin{array}{c}\text { Intervalse between Successive Litters(day) } \\
\text { mean } \pm \text { S.E. }\end{array}$ \\
\hline I & 30 & $94 \pm 3.1$ & $23 \pm 1.1$ \\
II & 30 & $118 \pm 3.2$ & $27 \pm 1.5$ \\
III & 30 & $143 \pm 4.1$ & $30 \pm 2.7$ \\
IV & 29 & $174 \pm 5.9$ & $31 \pm 2.1$ \\
V & 26 & $199 \pm 5.3$ & $29 \pm 1.9$ \\
VI & 24 & $228 \pm 5.4$ & $25 \pm 1.4$ \\
VII & 19 & $253 \pm 6.4$ & $37 \pm 7.1$ \\
VIII & 12 & $282 \pm 7.9$ & $23 \pm 8.5$ \\
IX & 7 & $302 \pm 9.4$ & $31 \pm 6.8$ \\
X & 3 & $313 \pm 10.7$ & \pm 1
\end{tabular}

は，301〜350日令のものは他の日令のものに比べ，また， 9,10産次のものは他の産次のものに比べ, それぞれ低 下しているが，高日令，高産次のものの総産仔数が少な いため，その差が有意であるかどうかは断定できない。

Table 3 に各産次の雌親の日令の平均之分婏間隔の 平均とをしめす。30ペアのうち $80 \%$ は 6 産次まで分婏し たが， 6 産次の平均日令は 228 日であった。分婏間隔は 産次間にバラッキが大きいが, 産次が進むにつれて開く 傾向がみられるようである。

次に, litter size および仔の性比について産次および 雌親の日令によって分類した結果を Table 4 および Table 5 にしめす。平均の litter size は 1 産次, 2 産 次と増加し， 3 産次の 6.9 が最高で，以降減少傾向を示 し， 3 産次に比へ有意に減少している。仔の性比につい ては産次による差は認められなかった (Table 4)。分婏 日令別にみた場合は，101〜150日令での litter size が
最高で，201 日令以降のそれは有意に減少した。仔の性 比については分婏日令による有意差は認められなかった (Table 5)。

分婏数, 産次数, 離乳数, 仔の性比, 最終分婏日令括 よび寿命の個体間の変異

これまでは雌親の日令と産次によって分類した繁殖能 力について比較したが，各個体（あるいはペア）間での 繁殖能力のいくつかの指標と寿命についてその変異を Table 6 に要約してしめす。分婏回数は 3 回から最高 10回まであり，その平均は 7 回であった。このうち死産 と分娩直後の食殺のあったものが 5 ペアで， 4 ペアは 2 回の死産あるいは食殺があった。

一生の間の総産仔数は12〜71匹で，平均41匹であった。 離乳数の平均は39匹で，離乳率は50\%という低いものが 1 ペアに認められた。仔の性比は総産仔数が少ない場合 には意味を持たないが，雌 1 に対して雄0.525～2.750ま 
Table 4. Litter size and sex ratio of offsprings classified by parity

\begin{tabular}{cccc}
\hline Parity & No. of Litters a) & Litter Size $($ mean \pm S. E.) & Sex Ratio \\
\hline 1 & 30 & $6.36 \pm 0.31$ & 0.948 \\
2 & 30 & $6.56 \pm 0.37$ & 0.989 \\
3 & 30 & $6.93 \pm 0.43$ & 1.166 \\
4 & 29 & $6.37 \pm 0.61$ & 0.989 \\
5 & 26 & $6.07 \pm 0.46$ & 1.051 \\
6 & 24 & $4.95 \pm 0.39$ & 1.061 \\
7 & 19 & $4.10 \pm 0.55$ & 0.902 \\
8 & 12 & $4.25 \pm 0.45$ & 1.125 \\
9 & 7 & $3.85 \pm 0.67$ & 1.250 \\
10 & 3 & $4.00 \pm 2.00$ & 1.000 \\
\hline
\end{tabular}

a) Number of litters includes still birth and litters cannibalized at birth, of which litter size is calculated as zero.

Table 5. Litter size and sex ratio of offsprings classified by the age of females

\begin{tabular}{|c|c|c|c|}
\hline Age & No of Litters a) & Litter Size $($ mean \pm S. E. $)$ & Sex Ratio \\
\hline-100 & 28 & $6.32 \pm 0.119$ & 0.923 \\
\hline $101-150$ & 60 & $6.98 \pm 0.264$ & 1.074 \\
\hline $151-200$ & 45 & $6.33 \pm 0.404$ & 1.021 \\
\hline $201-250$ & 39 & $4.92 \pm 0.371$ & 0.939 \\
\hline $251-300$ & 30 & $4.33 \pm 0.387$ & 1.131 \\
\hline $301-350$ & 7 & $2.57 \pm 0.782$ & 1.250 \\
\hline $351-400$ & 1 & 5.00 & 0.666 \\
\hline
\end{tabular}

a) Number of litters includes still birth and litters cannibalized at birth, of which litter size is calculated as zero.

Table 6. Lifetime reproductive performance and lifespan

\begin{tabular}{lccc}
\hline & No. of Mice & Range & Mean \\
\hline Number of Litters & 30 & $3-10$ & 7 \\
Number of Mice Born & 30 & $12-71$ & 40.8 \\
Number of Mice Weaned & 30 & $11-70$ & 39.6 \\
Percent Weaned & 30 & $50-100$ & \\
Sex Ratio of Offsprings & 30 & $0.525-2.750$ & \\
Mean Litter Size a) & 30 & $3.75-8.33$ & \\
Age at Last Litter & 30 & $128-352$ & 261.3 \\
Lifespan (female) & 25 & $621-944$ & $(737.4) \pm 15.1$ \\
\multicolumn{1}{c}{$\quad$ (male) } & 27 & $497-1006$ & $(731.4) \pm 24.1$ \\
\hline
\end{tabular}

a) Still birth and litters cannibalized at birth are omitted.

での変異があった。しかし，5ペアについては，その仔 の性比が統計的な 1 対 1 の期待值より有意に偏っており, このうち, 雄が有意に多いものが 4 例, 雌が有意に多い あのが 1 例であった。

平均の litter size は死産と分婏直後の食殺を除くと 3.7 8. 3であった。最終分婏日令は $128 〜 352$ 日令で, 平 均 261 日令であった。最終分婏日令と総産仔数との相関 は，最終分婏日令が早い場合には総産仔数が少なくなる ので当然期待されるが, 最終分婏日令のおそい個体が必
ずしも総産仔数が多い結果は得られなかった $(\gamma=0.42)$ 。 平均寿命は, 雌では記録の不備のため正確に死亡日令 が確認できなかった 5 個体を除き，621〜944日で，平均 737日，雄では同様の 3 個体を除き，497〜1,006 日で, 平均 731 日であった。

最終分婏日令および総産仔教と雌親の寿命との間には いずれも明らかな相関は認められなかった $(r=0.10, r$ $=0.06$ )。 
従来，われわれはこの系統のマウスを計画生産する場 合，雄 1 に対して雌 2 の交配を行ない，交配間隔を約50 日としてきた。この交配方式によると，すでに 3 産次で 1 産次, 2 産次に比較して litter size が減少し，それ 以降では著しく生産効率が低下することを経験している。 一般に，作業能率やスペースを考慮しなければ，生産効 率を高めるためには, single pair mating があっとも 良いことが報告されており $[1]$ ，また，妊孕性の低下は 飼料の組成に関連しておこる妊娠間隔の延長に伴う肥満 によるととが指摘されている $[4]$ 。本実験では， 1 対 1 の同居交配方法の場合，200日令以上あるいは，5産次 以上では litter size が減少する傾向はあっても，日令 250 日，産次数 6 産次までは妊孕性はそれほど低下しな いととが明らかとなった。とのことは動物の繁殖能力か らみて, 従来の生産方式がかなり能率のわるいむのであ ることを示唆している。したがって，作業能率を配慮し， 計画生産における交配方式，飼育管理方式を改良すれば， 生産効率をあげるととが可能であると考えられる。

繁殖能力については, 日令が進むにつれて litter size が減少すること，哺乳能力についても離乳率からみたと き多少減少する傾向があること，分婏間隔については， 分婏可能な期間であればそれほど延長が起らないととな どがそれぞれ認められた。これらの形質については，か なり系統によって差のあるととが報告されており [2]， 最終分婏日令については，C57BL/6J で平均 399 日，最 高 477 日令であるととが報告されている[5]。本実験の $\mathrm{C} 3 \mathrm{H}$ マウスでは，最終分婏日令からみれば，C57BLよ り早く妊孕性が失われるあのと考えられる。

Roderick と Storer[7]は系統間での litter size か らみた繁殖能力と寿命との間の関連について報告してい るが, 本実験では, 同一系統内の個体の寿命と総産仔数 あるいは最終分婏日令との相関は認められなかった。こ れらの事実は，加令に伴う繁殖生理学的変化を解析する 際の実験動物の選択にあたって一つの基礎資料を提供す るあのである。

仔の性比については, 日令や産次による偏りは認めら れなかったが，一つのペアの産仔についてみたとき，そ の性比が有意に期待值より偏る例が認められた。この原 因については今のとてろ全くわからないが，将来検討さ れるべき興味ある問題と考えられる。

近交系，あるいはそれらの交配による $F_{1}$ マウスの平均 寿命については, 従来から多くの報告があり, また, 寿 命に影響する種々の要因についてあ報告されているが [8], 最近 Festing と Blackmore は, 本実験と同様
の SPF で飼育された $\mathrm{C} 3 \mathrm{H}$ マウスの寿命について報告 している。彼等は，200日令で繁殖親から retire したマ ウスの平均寿命が雌で676日，雄で590日という結果を得 ている。これは本実験で得られた結果，すなわち，雌で 737日，雄で731日に比較してかなり短い。SPF という 飼育環境がかなり類似していると考えられるにも拘わら ず，同一系統でこのように異なる原因は， subline 化に 伴う遺伝的な差かあるいは飼料などの差によるあのか断 定することは困難であるが，長期間の飼育を伴う実験で は，遺伝的にも環境的にもかなり厳密なコントロールが なされなければ再現性のある結果が得られないことを示 唆するあのと考えられる。

なお，本実験に使用したマウスの病理学的検索結果に ついては別に報告する予定であるが，乳癌の発生率は約 33\%であり，上記の Festing と Blackmore[3]の結果 と大差のないことを附記する。また，前述のように，本 実験を行なった施設内で緑膿菌污染があったが、この励 染は本実験の繁殖成績の結果が得られたあとであり，ゲ ンタマイシン投与による繁殖成績への影響を考慮する必 要はないが，ゲンタマイシン投与後に繁殖生産を行なっ た他の群については繁殖が低下する結果を得ているので， このことああわせて附記する。

要

約

われわれは計画生産および長期飼育実験のための基礎 的資料を得るため，SPF で飼育されている $\mathrm{C} 3 \mathrm{H}$ マウ スの life time の繁殖成績と寿命について検討を行なっ た。生後64士 5 日から雌雄 1 対 1 の同居で飼育した結果, 総計210 litters, 1,226個体の仔が得られたが，その約 87 \%は雌親が 250 日令に達するまでに得られた。 litter size は, 3 産次, 雌親の日令101〜150日のあのがあっ と屯大きく, 以後減少する傾向が認められた。妊娠間隔 は産次が進んでもそれほど大きく開くことはなかった。 仔の性比は雌親の日令, 産次によって変動しなかったが, 各ペアについてみると，5ペアでその仔の性比が有意に 偏っていた。分婏回数はペア当り $3 \sim 10$ 回で平均 7 回, 総産仔数の平均はペア当り41匹であった。最終分婏日令 は128〜352日日，平均261日であった。寿命は雌が621〜 944日，平均737日，雄が 497〜1,006 日，平均731日であ った。雌親の寿命とその最終分娩日令や総産仔数との間 に相関は認められなかった。

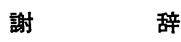

この論文について助言をいただいた動植物管理課福田宗一 氏に感謝する。また, この研究を行なうにあたって, 多大の 
ご協力をいただいた障害基礎研究部早川純一郎氏に厚くお礼 申し上げ, 動植物管理課山極順二, 松本恒弥両氏に梁く感謝 する。

\section{文献}

[1] Bruce, H. M. (1954). Feeding and breeding of laboratory animals. XIV. Size of breeding group and production of mice. J. Hyg., 52, 60-66.

[2] Festing, M. (1968). Some aspects of reproductive performance in inbred mice. Laboratory Animals, 2, 89-100.

[3] Festing, M. F. W. and Blackmore, D. K. and Blackmore, D. K. (1971). Life span of specified-pathogen-free (MRC category 4) mice and rats. Laboratory Animals, 5, 179-192.

[4] Hoag, W. G. and Dickie, M. M. (1966).
Nutrition. In Biology of the Laboratory Mouse (2nd ed.), Green, E. L. editor, McGrowHill Inc. New York, 39-43.

［5] 西村正彦 (1973) 第19回実験動物談話会記録（東 京， 1972 年 2 月）実験動物， $22 ， 64-65$

[6] Roberts, R. C. (1961). The lifetime growth and reproduction of selected strains of mice. Heredity, 16, 369-381.

[7] Roderick, T. H. and Storer, J. B. (1961). Correlation between litter size and mean life span among 12 inbred strains of mice. Science, $134,48-49$.

[8] Russell, E. S. (1966). Life span and aging patterns. In Biology of the Laboratory Mouse (2nd ed.), Green, E. L. editor, McGrow-Hill Inc. New York, 511-519. 